\title{
OPTIMALNI POREZ ZA JEDNO HOMOGENO DOBRO NA DVA TRŽIŠTA UZ TROŠKOVE IZVOZA KAO PROBLEM DVORAZINSKOG PROGRAMIRANJA
}

Oporezivanje je jedan od najmoćnijih instrumenata fiskalne politike koji ima značajne posljedice na ponudu i potražnju, utječe na ekonomski rast i investicije kao i na konkurentnost poduzeća. Također, utječe na poticaj poduzećima da ostanu u nekoj zemlji ili premjeste svoje poslovanje drugdje. Stoga je osmišljavanje optimalne porezne politike od presudnog značaja za svaku vladu. U ovom radu razmatra se problem određivanja optimalne porezne politike za jedno homogeno dobro koje proizvode dva konkurentska poduzeća smještena u dvije različite zemlje. Svako poduzeće ima jedan proizvodni pogon koji je smješten u zemlji iz koje poduzeće dolazi, dok se proizvod prodaje u obje zemlje. Države imaju različite porezne sustave. Ako poduzeće prodaje proizvod na stranom tržištu, uz trošak proizvodnje ima $i$ trošak izvoza koji se sastoji od troškova prijevoza i troškova carine. Problem se modelira kao problem programiranja s dva sljedbenika, pri čemu vođa (vlada) maksimizira porezni prihod dok sljedbenici (poduzeća) maksimiziraju svoje funkcije dobiti. Uz to što se formulira novi model koji do sada nije poznat u postojećoj literaturi, $u$ radu se izvodi optimalna razina poreza i pripadni iznos poreznog prihoda, izvode se optimalne razine proizvodnje $i$ izvoza poduzeća, razmatraju se svojstva funkcije dobiti i utjecaj povećanja poreza na optimalne količine i funkcije prihoda i dobiti poduzeća te se pokazuje kako se teret poreza raspodjeljuje između proizvođača i potrošača. Model se ilustrira numeričkim primjerom.

* Z. Lukač, dr. sc., redovita profesorica, Sveučilište u Zagrebu, Ekonomski fakultet (e-mail: zlukac@efzg.hr). Rad je primljen u uredništvo 16.11.2019. godine, a prihvaćen je za objavu 29.06.2020. godine. 
Z. LUKAČ: Optimalni porez za jedno homogeno dobro na dva tržišta uz troškove izvoza kao problem... EKONOMSKI PREGLED, 72 (6) 826-839 (2021)

Ključne riječi: dvorazinsko programiranje, troškovi izvoza, optimalna porezna politika, dva konkurentska poduzeća

\section{UVODNA RAZMATRANJA}

Svijet, u kojem živimo, svijet je sve veće globalizacije s poduzećima koja posluju na globalnoj razini. To se odnosi i na proizvodnju i na prodaju. Stoga je jedan od važnijih ciljeva svake vlade privlačenje investicija i poticanje konkurentnosti stvarajući tako radna mjesta, smanjujući stopu nezaposlenosti i potičući ekonomski rast. Fiskalna politika može pomoći vladama u postizanju takvih ciljeva pri čemu je porezna politika jedan od glavnih instrumenata. To uvelike utječe na raspoloživi dohodak, kao i na potrošnju i investicije, uključujući poticaj poduzećima da ostanu u nekoj zemlji ili da svoje poslovanje presele nekamo drugamo. Porezna politika ima važne posljedice na ponudu i potražnju, utječe na ekonomski rast i investicije kao i na konkurentnost poduzeća koja posluju u okviru određene porezne politike. Stoga je donošenje optimalne porezne politike od vrlo velike važnosti.

U ovom radu razmatra se jednostavni model dvaju tržišta s jednim homogenim dobrom. Dva poduzeća proizvode isto homogeno dobro pri čemu svako poduzeće ima jedan proizvodni pogon, i to u zemlji iz koje dolazi. Poduzeća proizvodnju plasiraju na oba tržišta pri čemu se kod plasmana na strano tržište javljaju troškovi izvoza koji se sastoje od troškova transporta i troška carine. Zemlje imaju različite porezne politike. U radu se zbog jednostavnosti pretpostavlja da je porez iznos koji se plaća po jedinici proizvoda. Vlada svake zemlje određuje iznos poreza u cilju maksimiziranja svog poreznog prihoda dok poduzeća žele maksimizirati dobit. Ovaj problem sadrži hijerarhijsku strukturu. Vlada djeluje prva i donosi odluku o iznosu poreza što utječe na optimalnu razinu proizvodnje i izvoza, kao i na funkcije dobiti poduzeća. S druge strane, razina proizvodnje i izvoza utječe na iznos poreznog prihoda. Stoga je prirodno modelirati ovaj problem kao problem dvorazinskog programiranja pri čemu je vlada zemlje vođa, a poduzeća su sljedbenici.

Problemi dvorazinskog programiranja (Bard (1984), Brackenand \& McGill (1973), Colson, Marcotte i Savard (2007), Simaan (1977)) razmatraju probleme optimizacije s hijerarhijskom strukturom. Donositelj odluke na gornjoj razini naziva se vođa dok se donositelji odluka na nižoj razini nazivaju sljedbenicima. Svaki od donositelja odluka optimizira vlastitu funkciju cilja uz određeni skup ograničenja. Model pretpostavlja da nema suradnje među donositeljima odluka. Međutim, svima su dostupne sve informacije, odnosno svi su upoznati s funkcijom cilja i ograničenjima ostalih igrača. Vođa prvi donosi odluku. Jednom kad on donese odluku, sljedbenici neovisno jedan o drugome, kao i o željama vođe, donose odluku, 
koja u skladu s ograničenjima, optimizira njihovu vlastitu funkciju cilja. Njihove odluke utječu na skup mogućih rješenja i vrijednost funkcije cilja vođe. Stoga, prilikom donošenja odluke vođa treba predvidjeti odgovor sljedbenika uzimajući u obzir da će oni raditi ono što je najbolje za njih same, a ne za njegovu funkciju cilja. Ovakve probleme prvi je opisao njemački ekonomist H. F. von Stackelberg (1934.), pa su oni poznati i pod imenom Stackelbergove igre.

Problem dvorazinskog programiranja s više sljedbenika može se formulirati kao

$$
\begin{aligned}
& \max _{\mathbf{x} \in X} F\left(\mathbf{x}, \mathbf{y}_{1}, \ldots, \mathbf{y}_{\mathbf{n}}\right) \\
& \text { uz uvjete } G\left(\mathbf{x}, \mathbf{y}_{1}, \ldots, \mathbf{y}_{\mathbf{n}}\right) \leq 0 \\
& \max _{\mathbf{y}_{i} \in Y_{i}} f_{i}\left(\mathbf{x}, \mathbf{y}_{\mathbf{1}}, \ldots, \mathbf{y}_{\mathbf{n}}\right) \quad i=1, \ldots, n \\
& \text { uz uvjete } g_{i}\left(\mathbf{x}, \mathbf{y}_{1}, \ldots, \mathbf{y}_{\mathbf{n}}\right) \leq 0
\end{aligned}
$$

gdje je $X$ skup svih dopustivih odluka vođe, $\mathbf{x} \in X$ je vektor odluke vođe, $Y_{i}$ je skup svih dopustivih odluka $i$-tog sljedbenika, $\mathbf{y}_{i} \in Y_{i}$ je vektor odluke $i$-tog sljedbenika, $i=1, \ldots, n, F\left(\mathbf{x}, \mathbf{y}_{1}, \ldots, \mathbf{y}_{\mathbf{n}}\right)$ je funkcija cilja vođe, $f_{i}\left(\mathbf{x}, \mathbf{y}_{1}, \ldots, \mathbf{y}_{\mathbf{n}}\right), i=1, \ldots, n$ je funkcija cilja $i$-tog sljedbenika, $i=1, \ldots, n, G\left(\mathbf{x}, \mathbf{y}_{1}, \ldots, \mathbf{y}_{\mathbf{n}}\right)$ opisuje ograničenja vođe, dok $g_{i}\left(\mathbf{x}, \mathbf{y}_{1}, \ldots, \mathbf{y}_{\mathbf{n}}\right), i=1, \ldots, n$ opisuje ograničenja svakog od $n$ sljedbenika.

S obzirom na važnost oporezivanja dostupna je brojna literatura o toj temi. Opsežni pregled različitih aspekata porezne politike nalazi se u serijalu Handbook of Public Economics series (vol. 1 (1985), vol. 2 (1987), vol. 3 (2002), vol. 4 (2002), vol. 5 (2013)). Što se tiče modela optimalne porezne politike koji uključuju dvije zemlje i poduzeća koja vrše proizvodnju, Brander i Spencer (1985) proučavaju učinak subvencija razmatrajući dvije zemlje izvoznice koje nesavršeno konkurentno dobro izvoze u treću zemlju. Problem se modelira kao jednostavan Cournotov duopol gdje vlada djeluje prva i određuje razinu subvencija prije nego što se odredi razina proizvodnje. Becker i Fuest (2011) razmatraju ulogu subvencija u poboljšanju relativnog položaja domaćih poduzeća u nekooperativnoj konkurenciji sa stranim poduzećima. Hondriks i Perlata (2014) promatraju dvije zemlje i dvije multinacionalne kompanije koje se natječu à la Cournot na lokalnim tržištima i rabe pomake u dobiti na temelju porezne diferencije. Kanbur i Keen (1993) donose jednostavan model porezne konkurencije za dvije zemlje pri čemu se fokus stavlja na utjecaj veličine zemlje. Problem se formulira kao nekooperativna (Nashova) ravnoteža. Wang (1999) razmatra model koji su predložili Kanbur i Keen (1993) i za njega razmatra Stackelbergovu ravnotežu i uspoređuje Stackelbergovu ravnotežu s Nashovom ravnotežom. Rad pokazuje da Stackelbergova ravnoteža strogo dominira ravnotežom Nash-a, u smislu da svaka od susjednih zemalja može prikupiti veće porezne prihode ako obje zemlje izaberu porezne stope proizišle iz Stackelbergove ravnoteže. 
Struktura je rada kako slijedi. U drugom poglavlju donosi se formulacija modela. Optimalna porezna politika kao i optimalne količine proizvodnje i izvoza za svako poduzeće prikazani su u trećem poglavlju. Četvrto poglavlje sadrži svojstva funkcije poreznog prihoda kao i učinak jediničnog povećanja poreza na optimalne količine proizvodnje i izvoza, i funkcije prihoda i profita poduzeća. Također, pokazuje se kako se teret jediničnog poreza raspodjeljuje između potrošača i proizvođača. Peto poglavlje ilustrira predloženi model numeričkim primjerom. Zaključci su prezentirani u zadnjem poglavlju.

\section{METODOLOGIJA I FORMULACIJA PROBLEMA}

U radu se razmatra sljedeći problem. Dva poduzeća proizvode isto homogeno dobro u dvije različite zemlje s istim jediničnim troškom proizvodnje. Svako poduzeće ima samo jedan proizvodni pogon koji je smješten u zemlji iz koje dolazi poduzeće. Poduzeća plasiraju proizvod na oba tržišta. Međutim, prilikom izvoza na strano tržište javlja se trošak izvoza koji se sastoji od troškova prijevoza i troška carine.

U radu se rabe sljedeće oznake:

c jedinični trošak proizvodnje

$q_{i j} \quad$ količina koju poduzeće $i$ prodaje na tržištu $j, i, j=1,2$

$c_{12} \quad$ jedinični trošak izvoza iz zemlje $1 \mathrm{u}$ zemlju 2

$c_{21} \quad$ jedinični trošak izvoza iz zemlje 2 u zemlju 1

$t_{i} \quad$ porez po jedinici proizvoda na tržištu $i, i=1,2$

$p_{i} \quad$ cijena koju primaju proizvođači na tržištu $i, i=1,2$

$p_{i}+t_{i}$ cijena koju plaćaju potrošači na tržištu $i, i=1,2$

Pritom se pretpostavlja da jedinični troškovi izvoza $c_{12}$ i $c_{2 l}$ uključuju jedinični trošak transporta i jedinični trošak carina. Također, zbog jednostavnosti, porez na tržištu $i, t_{i}$, izražen je kao iznos po jedinici proizvoda. Svako tržište formira vlastitu cijenu na osnovi mehanizma ponude i potražnje. Pritom $p_{i}$ označava cijenu koju primaju proizvođači na tržištu $i$ dok je cijena koju plaćaju kupci uvećana za iznos poreza, odnosno jednaka je $p_{i}+t_{i}$.

Daljnja je pretpostavka modela da je porezna politika države 2 unaprijed određena, odnosno iznos je poreza po jedinici proizvoda na drugom tržištu, $t_{2}$, fiksiran. Vlada države 1 treba donijeti odluku o porezu po jedinici proizvoda na prvom tržištu, $t_{1}$, koji će maksimizirati njezin porezni prihod. Ona pri donošenju 
ove odluke mora uzeti u obzir reakciju poduzećā koja, jednom kada se donese odluka o razini poreza u državi 1, donose odluku o razini proizvodnje i količinama plasmana na svakom od tržišta s ciljem dostizanja maksimalne dobiti. Vlada je države 1 vođa i djeluje prva, a poduzeća su sljedbenici. Jednom kad vlada donese odluku, poduzeća donose odluku neovisno jedno o drugom. Slika 1 donosi grafički prikaz ovog problema.

Slika 1.

GRAFIČKI PRIKAZ PROBLEMA

\section{Zemlja 1}

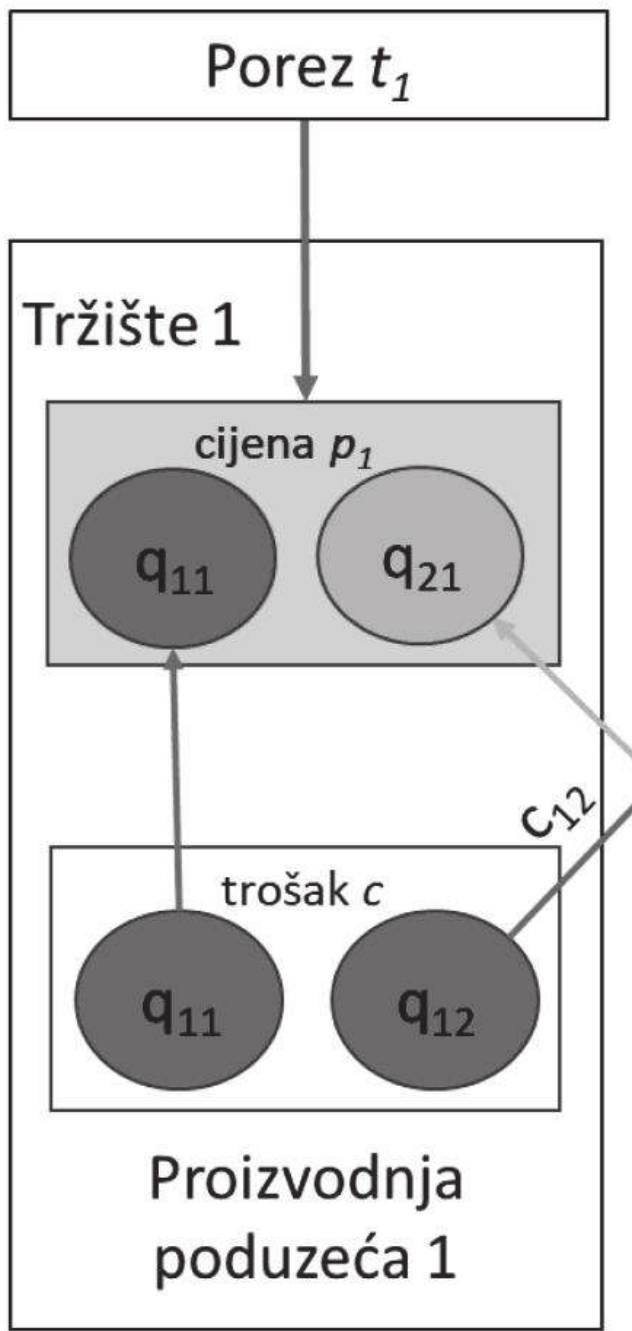

\section{Zemlja 2}

Porez $t_{2}$

\section{Tržište 2}

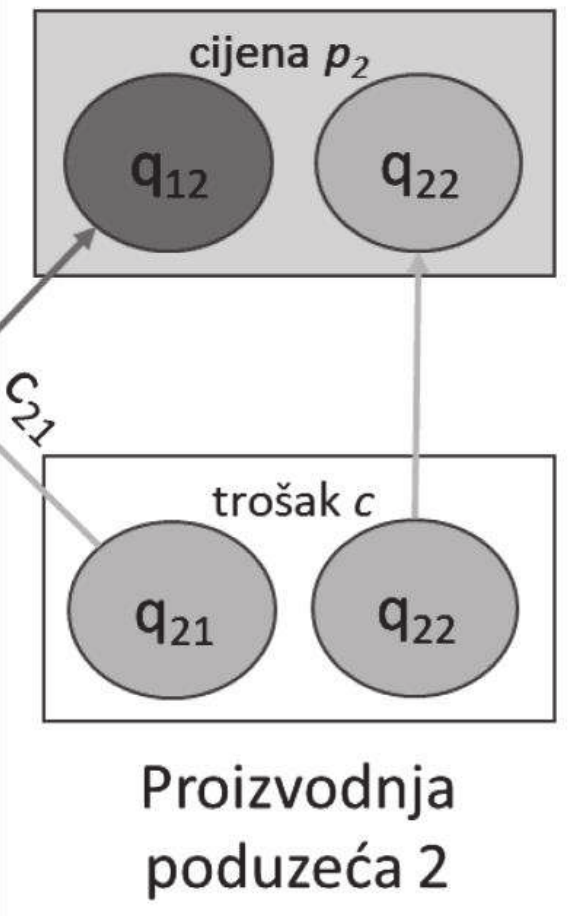


Primijetimo da je ukupna ponuda na prvom tržištu jednaka $q_{11}+q_{21}$ dok je ukupna ponuda na drugom tržištu jednaka $q_{12}+q_{22}$. Također, ukupna proizvodnja prvog poduzeća jednaka je $q_{11}+q_{12}$, dok je ukupna proizvodnja drugog poduzeća jednaka $q_{21}+q_{22}$. jednaka

Nadalje, pretpostavljamo da je inverzna funkcija potražnje na prvom tržištu

$$
p_{1}+t_{1}=a_{0}-a_{1} \cdot\left(q_{11}+q_{21}\right)
$$

dok je inverzna funkcija potražnje na drugom tržištu jednaka

$$
p_{2}+t_{2}=b_{0}-b_{1} \cdot\left(q_{12}+q_{22}\right)
$$

pri čemu su $a_{0}, a_{1}, b_{0}$ i $b_{1}$ pozitivne konstante. Primijetimo da su $p_{1}$ i $p_{2}$ cijene proizvoda prije poreza, tj. cijene koje primaju poduzeća, dok su $p_{1}+t_{1}$ su $p_{2}+t_{2}$ cijene koje na prvom i drugom tržištu plaćaju potrošači.

Funkcija poreznog prihoda vlade prve zemlje jednaka je

$$
T\left(t_{1} ; q_{11}, q_{21}\right)=t_{1} \cdot\left(q_{11}+q_{21}\right) .
$$

Pogledajmo sada prvo poduzeće čiji je proizvodni pogon smješten u zemlji 1. Funkcija prihoda tog poduzeća jednaka je

$$
R_{1}\left(q_{11}, q_{12} ; t_{1}\right)=p_{1} q_{11}+p_{2} q_{12}
$$

Uvrštavanjem relacija (2) i (3) u (5), funkcija prihoda prvog poduzeća može se izraziti kao

$$
R_{1}\left(q_{11}, q_{12} ; t_{1}\right)=-a_{1} q_{11}^{2}+\left(a_{0}-t_{1}-a_{1} q_{21}\right) q_{11}-b_{1} q_{12}^{2}+\left(b_{0}-t_{2}-b_{1} q_{22}\right) q_{12} .
$$

Kako je funkcija troškova prvog poduzeća jednaka

$$
C_{1}\left(q_{11}, q_{12} ; t_{1}\right)=c \cdot\left(q_{11}+q_{12}\right)+c_{12} q_{12},
$$

to je njezina funkcija dobiti jednaka

$$
\Pi_{1}\left(q_{11}, q_{12} ; t_{1}\right)=R_{1}\left(q_{11}, q_{12} ; t_{1}\right)-C_{1}\left(q_{11}, q_{12} ; t_{1}\right),
$$

odnosno

$$
\Pi_{1}\left(q_{11}, q_{12} ; t_{1}\right)=-a_{1} q_{11}^{2}+\left(a_{0}-t_{1}-a_{1} q_{21}-c\right) q_{11}-b_{1} q_{12}^{2}+\left(b_{0}-t_{2}-b_{1} q_{22}-c-c_{12}\right) q_{12} \text {. }
$$


Izračunajmo sada funkcije prihoda, troškova i dobiti drugog poduzeća. Kako je

$$
R_{2}\left(q_{21}, q_{22} ; t_{1}\right)=p_{1} q_{21}+p_{2} q_{22},
$$

tako uvrštavanjem relacija (2) i (3) u (10) funkcija prihoda drugog poduzeća može se izraziti kao

$$
R_{2}\left(q_{21}, q_{22} ; t_{2}\right)=-a_{1} q_{21}^{2}+\left(a_{0}-t_{1}-a_{1} q_{11}\right) q_{21}-b_{1} q_{22}^{2}+\left(b_{0}-t_{2}-b_{1} q_{12}\right) q_{22} .
$$

Funkcija troškova drugog poduzeća jednaka je

$$
C_{2}\left(q_{21}, q_{22} ; t_{1}\right)=c \cdot\left(q_{21}+q_{22}\right)+c_{21} q_{21},
$$

pa je njezina funkcija dobiti jednaka

$$
\Pi_{2}\left(q_{21}, q_{22} ; t_{1}\right)=R_{2}\left(q_{21}, q_{22} ; t_{1}\right)-C_{1}\left(q_{21}, q_{22} ; t_{1}\right)
$$

odnosno

$\Pi_{2}\left(q_{21}, q_{22} ; t\right)=-a_{1} q_{21}^{2}+\left(a_{0}-t_{1}-a_{1} q_{11}-c-c_{21}\right) q_{21}-b_{1} q_{22}^{2}+\left(b_{0}-t_{2}-b_{1} q_{12}-c\right) q_{22}$

Sada se razmatrani problem može zapisati kao problem dvorazinskog programiranja (15)-(17):

$$
\max _{t_{1} \geq 0} T\left(t_{1} ; q_{11}, q_{21}\right)=t_{1} \cdot\left(q_{11}+q_{21}\right)
$$

uz ograničenja

$$
\begin{aligned}
& \max _{q_{11}, q_{12} \geq 0} \Pi_{1}\left(q_{11}, q_{12} ; t_{1}\right) \\
& \max _{q_{21}, q_{22} \geq 0} \Pi_{2}\left(q_{21}, q_{22} ; t_{1}\right)
\end{aligned}
$$

Vođa, odnosno vlada prve zemlje, djeluje prva i donosi odluku o iznosu poreza po jedinici proizvoda $t_{1}$. Međutim, pri donošenju te odluke mora voditi računa o tome da će poduzeća, nakon jednom donesene odluke o porezu, neovisno jedno o drugome, kao i o vladi zemlje, sama donijeti odluku o razini proizvodnje i izvoza $\mathrm{s}$ ciljem maksimizacije njihove funkcije dobiti.

\section{RJEŠENJE MODELA}

Da bi se dobilo optimalno rješenje problema (15)-(17), prvo se razmatra problem optimizacije svakog sljedbenika. Za danu odluku o razini poreza $t_{1}$, razma- 
traju se nužni uvjeti za optimalno rješenje problema sljedbenika. Za problem (16), iz nužnih uvjeta za prvo poduzeće dobiva se sustav

$$
\begin{gathered}
\frac{\partial \Pi_{1}}{\partial q_{11}}=-2 a_{1} q_{11}-a_{1} q_{21}+a_{0}-t_{1}-c=0 \\
\frac{\partial \Pi_{1}}{\partial q_{12}}=-2 b_{1} q_{12}-b_{1} q_{22}+b_{0}-t_{2}-c-c_{12}=0
\end{gathered}
$$

dok za problem (17), odnosno iz nužnih uvjeta za drugo poduzeće slijedi

$$
\begin{gathered}
\frac{\partial \Pi_{2}}{\partial q_{21}}=-a_{1} q_{11}-2 a_{1} q_{21}+a_{0}-t_{1}-c-c_{21}=0 \\
\frac{\partial \Pi_{2}}{\partial q_{22}}=-b_{1} q_{12}-2 b_{1} q_{22}+b_{0}-t_{2}-c=0
\end{gathered}
$$

Rješavanjem sustava linearnih jednadžbi (18)-(21), za danu i fiksiranu razinu poreza $t_{1}$, za svako poduzeće dobivaju se optimalne količine proizvodnje i plasmana na svako tržište:

$$
\begin{aligned}
q_{11}^{*}\left(t_{1}\right) & =\frac{a_{0}-t_{1}-c+c_{21}}{3 a_{1}}, \\
q_{12}^{*}\left(t_{1}\right) & =\frac{b_{0}-t_{2}-c-2 c_{12}}{3 b_{1}}, \\
q_{21}^{*}\left(t_{1}\right) & =\frac{a_{0}-t_{1}-c-2 c_{21}}{3 a_{1}}, \\
q_{22}^{*}\left(t_{1}\right) & =\frac{b_{0}-t_{2}-c+c_{12}}{3 b_{1}} .
\end{aligned}
$$

Može se primijetiti da, očekivano, optimalna količina izvoza prvog poduzeća na drugo tržište, $q_{12}^{*}\left(t_{1}\right)$, i optimalna količina koju drugo poduzeće plasira na domaće tržište, $q_{22}^{*}\left(t_{1}\right)$, ne ovise o razini poreza $t_{1}$. Također, funkcije $q_{11}^{*}\left(t_{1}\right)$ i $q_{21}^{*}\left(t_{1}\right)$ imaju isti nagib. Drugim riječima, jedinično će povećanje poreza $t_{1}$ smanjiti optimalne količine $q_{11}^{*}\left(t_{1}\right)$ i $q_{21}^{*}\left(t_{1}\right)$ koje poduzeća plasiraju na prvom tržištu za $\frac{1}{3 a_{1}}$. Nadalje, s obzirom na to da količine moraju biti nenegativne, iz relacija (22)-(25) možemo zaključiti da vrijede sljedeće gornje ograde na razine poreza $t_{1}$ i $t_{2}$ :

$$
\begin{aligned}
& t_{1} \leq a_{0}-c-2 c_{21}, \\
& t_{2} \leq b_{0}-c-2 c_{12} .
\end{aligned}
$$


Uvrštavanjem relacija (22) i (24) u (15) dobivamo funkciju poreznog prihoda prve zemlje (4) kao funkciju poreza $t_{1}$ :

$$
T\left(t_{1}\right)=-\frac{2}{3 a_{1}} t_{1}^{2}+\frac{2 a_{0}-2 c-c_{21}}{3 a_{1}} t_{1} .
$$

Sada se može promatrati optimizacijski problem vođe, odnosno vlade prve zemlje. Primjenom nužnih uvjeta na $(28)$, dobiva se optimalna razina poreza $t_{1}^{*} \mathrm{i}$ pripadni maksimalni porezni prihod $T\left(t_{1}^{*}\right)$ :

$$
\begin{gathered}
t_{1}^{*}=\frac{2 a_{0}-2 c-c_{21}}{4}, \\
T\left(t_{1}^{*}\right)=\frac{1}{24 a_{1}}\left(2 a_{0}-2 c-c_{21}\right)^{2} .
\end{gathered}
$$

Za fiksiranu optimalnu odluku vođe $t_{1}^{*}$ i fiksiranu odluku o razini poreza $\mathrm{u}$ drugoj zemlji $t_{2}$ uvrštavanjem relacije (29) u (22)-(25) dobiva se optimalna razina proizvodnje i izvoza svakog poduzeća:

$$
\begin{aligned}
& q_{11}^{*}\left(t_{1}^{*}\right)=\frac{2 a_{0}-2 c+5 c_{21}}{12 a_{1}} \\
& q_{12}^{*}\left(t_{1}^{*}\right)=\frac{b_{0}-t_{2}-c-2 c_{12}}{3 b_{1}} \\
& q_{21}^{*}\left(t_{1}^{*}\right)=\frac{2 a_{0}-2 c-7 c_{21}}{12 a_{1}} \\
& q_{22}^{*}\left(t_{1}^{*}\right)=\frac{b_{0}-t_{2}-c+c_{12}}{3 b_{1}}
\end{aligned}
$$

\section{SVOJSTVA KOJA PROIZLAZE IZ MODELA}

Kako je druga derivacija funkcije poreznog prihoda (28) negativna, riječ je o konkavnoj funkciji koja, očekivano, zadovoljava svojstva Lafferove krivulje (Gahvari (1989)). Kako je

$$
T^{\prime}\left(t_{1}\right)=-\frac{4}{3 a_{1}} t_{1}+\frac{2 a_{0}-2 c-c_{21}}{3 a_{1}},
$$

odnosno

$$
T^{\prime}\left(t_{1}\right)=-\frac{4}{3 a_{1}}\left(t_{1}-t_{1}^{*}\right),
$$


to funkcija poreznih prihoda (28) raste za $t_{1}<t_{1}^{*}$ i pada za $t_{1}>t_{1}^{*}$.

Promotrimo sada utjecaj jediničnog povećanja poreza $t_{1}$ na cijenu $p_{1}$ koju poduzeća primaju i cijenu $p_{1}+t_{1}$ koju potrošači plaćaju u prvoj zemlji. Drugim riječima, potrebno je vidjeti kako se raspodjeljuje porez, odnosno koji dio plaćaju proizvođači, a koji potrošači. Uvrštavanjem relacija (22) i (24) u (2), dobiva se cijena koju poduzeća primaju na prvom tržištu kao funkciju iznosa poreza $t_{1}$ :

$$
p_{1}\left(t_{1}\right)=\frac{1}{3}\left(a_{0}+2 c+c_{21}\right)-\frac{1}{3} t_{1} .
$$

Sada je

$$
\frac{d p_{1}}{d t_{1}}=-\frac{1}{3}
$$

i

$$
\frac{d\left(p_{1}+t_{1}\right)}{d t_{1}}=\frac{2}{3} .
$$

Stoga, kad god vlada prve zemlje poveća porez za 1, cijena, koju primaju poduzeća u toj zemlji, smanjit će se za 1/3, dok će se cijena, koju plaćaju potrošači, povećati za 2/3. Drugim riječima, od svake jedinice poreza, koji se slijeva u državnu blagdanu, 1/3 dolazi od poduzeća dok 2/3 dolaze od potrošača.

Kako se mijenja iznos poreza, mijenjaju se i optimalne količine proizvodnje i izvoza. Kako je

$$
\frac{d q_{11}^{*}\left(t_{1}\right)}{d t_{1}}=-\frac{1}{3 a_{1}}, \quad \frac{d q_{12}^{*}\left(t_{1}\right)}{d t_{1}}=0
$$

i

$$
\frac{d q_{21}^{*}\left(t_{1}\right)}{d t_{1}}=-\frac{1}{3 a_{1}}, \quad \frac{d q_{22}^{*}\left(t_{1}\right)}{d t_{1}}=0,
$$

to će se, uslijed povećanja poreza na prvom tržištu za jednu novčanu jedinicu, ukupna ponuda na prvom tržištu smanjiti za

$$
\frac{d q_{11}^{*}\left(t_{1}\right)}{d t_{1}}+\frac{d q_{21}^{*}\left(t_{1}\right)}{d t_{1}}=-\frac{2}{3 a_{1}} .
$$

Utjecaj jediničnog povećanja poreza s razine $t_{1}$ na razinu $t_{1}+1$ na funkcije prihoda i dobiti poduzeća opisan je relacijama (42)-(45):

$$
\frac{\partial R_{1}}{\partial t_{1}}=\frac{2}{9 a_{1}} t_{1}-\frac{2 a_{0}+c+2 c_{21}}{9 a_{1}},
$$




$$
\begin{gathered}
\frac{\partial \Pi_{1}}{\partial t_{1}}=\frac{2}{9 a_{1}} t_{1}-\frac{2 a_{0}-2 c+2 c_{21}}{9 a_{1}}, \\
\frac{\partial R_{2}}{\partial t_{1}}=\frac{2}{9 a_{1}} t_{1}-\frac{2 a_{0}+c-c_{21}}{9 a_{1}}, \\
\frac{\partial \Pi_{2}}{\partial t_{1}}=\frac{2}{9 a_{1}} t_{1}-\frac{2 a_{0}-2 c-4 c_{21}}{9 a_{1}} .
\end{gathered}
$$

\section{NUMERIČKI PRIMJER}

U ovom se poglavlju model (15-17) ilustrira numeričkim primjerom. Neka su inverzne funkcije potražnje na prvom i drugom tržištu zadane relacijama (46) i (47):

$$
\begin{aligned}
& p_{1}+t_{1}=100-5 \cdot\left(q_{11}+q_{21}\right) \\
& p_{2}+t_{2}=150-8 \cdot\left(q_{12}+q_{22}\right),
\end{aligned}
$$

neka je trošak proizvodnje jednak $c=4$, neka je razina poreza u drugoj zemlji jednaka $t_{2}=1$ i neka troškovi izvoza iznose $c_{12}=1 \mathrm{i} c_{21}=2$.

Funkcija poreznog prihoda prve zemlje sada se može izraziti kao funkcija poreza $t_{1}$ :

$$
T\left(t_{1}\right)=-\frac{2}{15} t_{1}^{2}+\frac{190}{15} t_{1}
$$

Optimalna razina poreznog prihoda dostiže se za razinu poreza $t_{1}^{*}=47.5$, te iznosi $T\left(t_{1}^{*}\right)=300.83$. Pritom su optimalne razine proizvodnje i plasmana na tržišta jednake $q_{11}^{*}=3.37, q_{12}^{*}=5.96, q_{21}^{*}=2.97 \mathrm{i} q_{22}^{*}=340.06$. Uz takvu poreznu politiku, optimalne razine dobiti poduzeća iznose $\Pi_{1}^{*}=340.67$ i $\Pi_{2}^{*}=340.06$ redom. Slika 2 prikazuje graf funkcije poreznog prihoda vođe, kao i ponudu $q_{11}+q_{21}$ i cijenu $p_{1}+t_{1}$ na prvom tržištu kao funkcije poreza $t_{1}$. 
Slika 2.

GRAF FUNKCIJE POREZNOG PRIHODA PRVE ZEMLJE $T\left(t_{1}\right)$, PONUDE $q_{11}+q_{21}$ I CIJENE $p_{1}+t_{1}$ NA PRVOM TRŽIŠTU KAO FUNKCIJE POREZA $t_{1}$

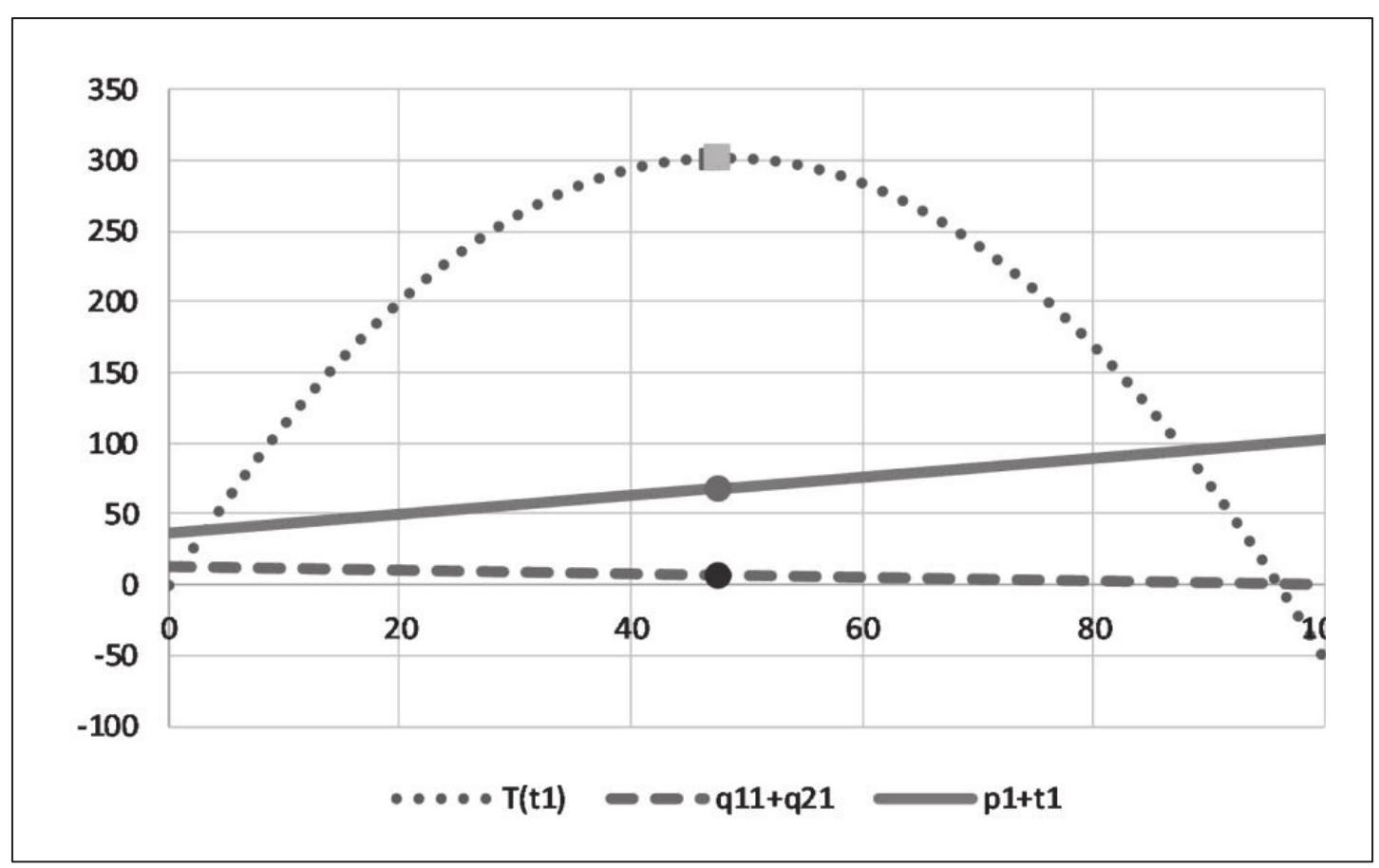

Izvor: Autor

\section{ZAKLJUČAK}

U ovom radu formulira se model dvorazinskog programiranja za rješavanje problema određivanja optimalne porezne politike vlade koja maksimizira porezni prihod uz postojanje dva konkurentska poduzeća koja proizvode isto homogeno dobro. Pritom svako poduzeće ima jedan proizvodni pogon koji je smješten u zemlji iz koje poduzeće dolazi, a proizvode plasira na oba tržišta. Nadalje, pri izvozu je prisutan trošak izvoza koji se sastoji od troškova prijevoza i carine. Prema saznanjima autora, u postojećoj literaturi ovakav model nije poznat. U radu se izvode formule za optimalnu razinu poreza, optimalni porezni prihod, kao i optimalne količine proizvodnje i izvoza. Također, pokazuju se svojstva funkcije dobiti i učinak jediničnog povećanja poreza na optimalne količine, funkcije prihoda i dobiti poduzeća. Nadalje, pokazano je kako se teret poreza raspodjeljuje između proizvo- 
đača i potrošača. Konačno, model je ilustriran numeričkim primjerom. U daljnjem istraživanju razmatrat će se generalizacija problema, odnosno problem optimalne porezne politike u slučaju kad isto homogeno dobro proizvodi $n$ poduzeća iz $n$ različitih zemalja, uz različite jedinične troškove proizvodnje, i proizvod plasiraju na sva tržišta, pri čemu se pri izvozu javlja trošak izvoza.

\section{LITERATURA}

1. Auerbach, A. J. i Feldstein, M. (Ur.) (1985). Handbook of Public Economics, vol. 1. Elsevier.

2. Auerbach, A. J. i Feldstein, M. (Ur.) (1987). Handbook of Public Economics, vo1. 2. Elsevier.

3. Auerbach, A. J. i Feldstein, M. (Ur.) (2002). Handbook of Public Economics, vo1. 3. Elsevier.

4. Auerbach, A. J. i Feldstein, M. (Ur.) (2002). Handbook of Public Economics, vo1. 4. Elsevier.

5. Auerbach, A. J., Chetty, R., Feldstein, M. i Saez, E. (Ur.) (2013). Handbook of Public Economics, Vol. 5. Elsevier

6. Bard, J. F. (1984). Optimality conditions for the bilevel programming problem. Naval Research Logistics Quarterly, 31, 13-26. doi: 10.1002/nav.3800310104

7. Becker, J. i Fuest, C. (2011). Optimal tax policy when firms are internationally mobile. International Tax and Public Finance, 18(5), 580-604. doi: 10.1007/ s10797-011-9168-X

8. Brackenand, J. i McGill, M. (1973). Mathematical Programs with Optimization Problems in the constraints. Operations Research, 21(1), 37-44. doi: 10.1287/opre.21.1.37

9. Brander, J.A. i Spencer, B.J. (1985). Export Subsidies and International Market Share Rivalry. Journal of International Economics, 18(1-2), 83-100, doi: 10.1016/0022-1996(85)90006-6

10. Colson, B., Marcotte, P. i Savard, G. (2007). An overview of bilevel optimization. Annals of Operations Research, 153(1), 235-256. doi: 10.1007/s10479007-0176-2

11. Hindriks, J., Perlata, S. i Weber, S. (2014). Local Taxation of Global Corporation: A Simple Solution, Annals of Economics and Statistics, 113/114, Special Issue On The Economics Of Taxation, 37-65. 
12. Gahvari, F. (1989). The nature of government expenditures and the shape of the Laffer curve. Journal of Public Economics, 40(2), 251-260. doi: 10.1016/0047-2727(89)90006-6

13. Keen, M. i Kanbur, R. (1993). Jeux Sans Frontieres: Tax Competition and Tax Coordination When Countries Differ in Size. American Economic Review, 83, 877-92.

14. Simaan, M. (1977). Stackelberg optimization of two-level systems. IEEE Transactions on Systems, Man and Cybernetics SMC-7 (4), 554-556.

15. von Stackelberg, H. (1934) Marktform und Gleichgewicht (in German). Wien, Verlag von Julius Springer.

16. Wang, Y.-Q. (1999).Commodity Taxes Under Fiscal Competition: Stackelberg Equilibrium and Optimality. American Economic Review, 89(4), 974-981. doi:10.1257/aer.89.4.974

\author{
OPTIMAL TAX POLICY FOR A SINGLE HOMOGENEOUS COMMODITY ON \\ TWO MARKETS WITH EXPORT COSTS AS A BILEVEL PROGRAMMING PROBLEM
}

Summary

Taxation is one of the most powerful instruments of fiscal policy, having important implications on supply and demand, affecting economic growth and investments as well as the competitiveness of companies operating under a given tax policy. It also affects a company's incentive to stay or to move its operations elsewhere. Therefore, designing the optimal tax policy is of crucial importance for any government. This study considers the problem of determining optimal tax policy for a single homogeneous commodity produced by two competing companies located in two different countries. Each company has one manufacturing facility located in its country of origin, while the product is sold in both countries. Countries have different tax systems. If a company sells the product on a foreign market, in addition to the cost of production there is also an export cost, which consists of transportation cost and duty cost. The problem is modelled as a bilevel programming problem with two followers, where the leader (the government) maximizes the tax revenue, whereas followers (companies) maximize their profit functions. In addition to formulating a new model that is not known in the existing literature so far, the paper derives the optimal tax level and the corresponding maximum amount of tax revenue, as well as the optimal production and export levels for the companies. It discusses the properties of the profit function and the impact of increasing taxes on optimal quantities and revenue and profit functions of the companies. Finally, it shows how the burden of tax is divided between producers and consumers. The model is illustrated by numerical example.

Key words: bilevel programming, export costs, optimal tax policy, two competing companies 